\title{
PENINGKATAN KESEJAHTERAAN MASYARAKAT MELALUI PENDIDIKAN, PEMBERDAYAAN EKONOMI, PENINGKATAN SARANA DAN PRASARANA SERTA KESEHATAN DI KOTA GUNUNG SITOLI: IMPLEMENTASI CORPORATE SOCIAL RESPONSIBILITY (CSR) PT. PERTAMINA (PERSERO) MARKETING OPERATING REGION (MOR) I - TERMINAL BAHAN BAKAR MINYAK (TBBM) GUNUNG SITOLI
}

\author{
Pasca Dwi Putra $^{1 *}$, Muhammad Nasir ${ }^{1}$, Noni Rozaini ${ }^{1}$ \\ ${ }^{1}$ Fakultas Ekonomi, Universitas Negeri Medan, Medan, Indonesia \\ *Penulis Korespondensi: sgacenter@gmail.com
}

\begin{abstract}
Abstrak
Peran penting PT Pertamina (Persero) MOR I - TBBM Gunung Sitoli dalam menginplementasikan kegiatan CSR bertujuan untuk meningkatkan kesejahteraan masyarakat melalui berbagai kegiatan sosial. Kegiatan ini dilakukan di Desa Humene Kota Gunung Sitoli Kabupaten Nias. Adapun kegiatan dilakukan berupa: 1) revitalisasi sarana pendukung pembelajaran dan bantuan pendidikan, 2) pengembangan produk makanan ringan, 3) pipanisasi saluran air bersih bagi masyarakat, 4) optimalisasi peran posyandu SEHATI. Hasil pengamatan secara kualitatif menunjukkan bahwa adanya peningkatan kesejahteraan dan kesehatan masyarakat melalui pelaksanaan kegiatan dimana revitalisasi meningkatkan minat belajar siswa serta keinginan melanjutkan pendidikan yang lebih tinggi melalui bantuan dana pendidikan. Adanya diversifikasi produk makanan ringan sehingga berdampak terhadap peningkatan pendapatan masyarakat. Perbaikan pola hidup masyarakat dan peningkatan kesehatan balita melalui program pipanisasi air bersih dan peran posyandu SEHATI. Pada akhirnya, kegiatan ini bermanfaat untuk peningkatan kesejahteraan dan kesehatan masyarakat secara umum.
\end{abstract}

Kata Kunci: Kesejahteraan Masyarakat, Revitalisasi, Diversifikasi Produk, Pipanisasi, Peran Posyandu, Kota Gunungsitoli

\begin{abstract}
The important role of PT Pertamina (Persero) MOR I - TBBM Gunung Sitoli in implementing CSR activities aims to improve the welfare of the community through various social activities. This activity was carried out in Humene Village of Gunung Sitoli City at the District of Nias. The activities were carried out in the form of: 1) revitalization of supporting facilities for learning and educational assistance, 2) development of snack products, 3) pipeline pipelines for the community, 4) optimization of the role of SEHATI's integrated service unit (abbreviated in local term as Posyandu). The qualitative observations show that there is an increase in community welfare and health through the implementation of activities where revitalization increases students' learning interest and the desire to continue higher education through education funding. There is a diversification of snack products that have an impact on increasing people's income. Improving the lifestyle of the community and improving the health of children under five through the clean water pipeline program and the role of the SEHATI's posyandu. In the end, this activity is beneficial for improving the welfare and health of the general public.
\end{abstract}

Keywords: Community Welfareness, Revitalization of Posyandu, Product Diversification, Piping, Gunungsitoli City

\section{PENDAHULUAN}

Indonesia merupakan negara yang memiliki kekayaan yang melimpah. Adanya sumber daya yang melimpah ini menjadi modal dalam membangun dan mensejahterkan masyarakat (Hasanah, 2015). Pemanfaatan sumber daya alam oleh pemerintah dan perusahaan bertujuan akhir dalam membangun perekonomian negara dan daerah. Oleh karena itu, pemanfaatan SDA merupakan salah satu prioritas utama negara sebagai modal dalam pemerataan kesejahteraan masyarakat serta agenda utama dalam membangun negara (Budiarti \& Santoso, 2014; Probosiwi, 2016). Tetapi tanpa disadari bahwa pemanfaatan SDA yang menghasilkan pajak yang bertujuan membangun negara dan mensejahterakan masyarakan menjadi eksploitasi yang berdampak 
terhadap kerusakan lingkungan seperti minyak bumi dan gas alam (Hasanah, 2015) sehingga perlu dilakukan pengurangan dampak negatif dari kerusakan lingkungan melalui program sosial seperti corporate social responsibility (CSR) oleh perusahaan yang bergerak diwilayah tersebut. CSR merupakan tanggung jawab perusahaan baik dibidang sosial maupun lingkungan dalam rangka mewujudkan suatu pembangunan yang berkelanjutan (Ernawan, 2014; Mapisangka, 2009; Suparman, 2013). Konsep dari CSR melaksanakan kegiatan yang didasarkan pada triple bottom line theory yaitu berfokus pada profit, people, dan planet (Hasanah, 2015).

Peran korporasi dalam peningkatan kesejahteraan masyarakat seyogyanya menjadi mitra dari pemerintah saja yang diwujudkan melalui penyaluran CSR dengan partisipasi dari masyarakat penerima manfaat. Ikut sertanya elemen tersebut menunjukkan tanggung jawab dalam mencapai pembangunan nasional yang adil dan merata. Adanya peran serta masyarakat dan badan usaha membantu mempercepat pembangunan nasional serta meningkatkan kesejahteraan masyarakat (Budiarti \& Santoso, 2014). Sekarang ini, kita lihat banyak permasalahan yang dihadapi masyarakat seperti pendidikan, ekonomi. Ketersediaan sarana dan prasarana serta kesehatan. Permasalahan tersebut saling berkaitan sehingga dalam menyelesaikannya perlu kesinambungan penyelesaian faktor-faktor tersebut. Dengan adanya agenda CSR yang terdiri dari 7 bidang diharapkan dapat membantu pemerintah dalam menyelesaikan permasalahan masyarakat (Hasanah, 2015).

Pemerintah khususnya daerah melalui masyarakat memiliki peranan dengan ikut serta mensukseskan pembangunan daerah dengan melaksanakan kegiatan dan membangun sarana dan prasarana. Pemerintah melakukan pembinaan kepada masyarakat agar lebih mandiri dalam menyelesaikan permasalahan. Sedangkan badan usaha melalui program sosial seperti corporate social responsibility (CSR) memberikan pelatihan dan pendampingan program kesejahteraan yang bertujuan juga memandirikan masyarakat. Adapun program-program tersebut akan memberikan manfaat kepada masyarakat yang pada akhirnya berdampak terhadap peningkatan kesejahteraan. Tetapi dalam memberikan program tersebut harus lebih berhati-hati agar tidak menyebabkan masyarakat bergantung kepada perusahaan ataupun pemerintah (Budiarti \& Santoso, 2014). Hal ini dikarenakan, dengan memberikan bantuan baik dana maupun program kegiatan menyebabkan masyarakat kurang mandiri dalam menyelesaikan masalah dan berdampak terhadap ketergantungan.

Salah satunya di Kota Gunungsitoli Provinsi Sumatera Utara. Kota Gunungsitoli merupakan salah satu kota yang diresmikan pada tanggal 29 Oktober 2008 yang merupakan pemekaran dari Kabupaten Nias. Luas wilayah yang dimiliki sebesar 469,36 km². Jumlah penduduk pada Kota Gunungsitoli ini sebanyak
135.995 jiwa. Kota ini memiliki 6 Kecamatan yang salah satunya adalah Kec. Gunungsitoli Idanoi. Kecamatan ini mempunya luas $134,78 \mathrm{~km}^{2}$ dimana memiliki 26 desa dan merupakan kecamatan terluas di Kota Gunungsitoli. Bentuk geografis kecamatan ini sebagian besar berupa daerah pesisir pantai dan memiliki wilayah kecil berupa bukit dan lembah. Salah satu desa yang terdapat pada kecamatan ini adalah Desa Humene dimana memiliki luas sebesar $2,48 \mathrm{~km}^{2}$ atau sebesar $1,84 \%$ dari total keseluruhan luas wilayah kecamatan. Desa ini terletak dipesisir pantai sehingga banyak mata pencaharian penduduknya adalah nelayan. Sebagian besar penduduk desa tersebut memiliki tingkat pendidikan yang rendah. Kepala desa hanya memiliki tingkat pendidikan setara SMA. Jumlah penduduk pada desa ini sebesar 642 jiwa yang terdiri dari 329 laki-laki dan 313 perempuan. Di Desa Humene ini hanya memiliki satu sarana pendidikan berupa Sekolah Dasar sehingga bagi masyarakat yang ingin melanjutkan pendidikannya lebih tinggi mengharuskan pergi kedesa lain atau ke kecamatan. Jumlah peserta didik sekolah dasar pada desa ini sebanyak 143 murid pada 1 sekolah. Sedangkan jumlah guru sebanyak 12 orang. Pada desa ini tidak terdapat rumah sakit ataupun puskesmas hanya memiliki 1 posyandu sehingga masyarakat yang sakit harus berobat pada posyandu ataupun pergi ke desa terdekat yang memiliki fasilitas kesehatan yang lebih lengkap. Disamping itu, tenaga kesehatan yang dimiliki pada desa ini hanya bidan sehingga kurang memiliki ketrampilan dalam bidang kesehatan dan menjadi faktor kurangnya kesadaran masyarakat akan pentingnya kesehatan bagi diri mereka pribadi.

Adapun jumlah usaha yang dimiliki masyarakat di Desa Humene ini terdiri dari 1 usaha menengah, 2 usaha kecil, dan 10 usaha mikro. Jumlah tersebut sudah tergolong besar dibandingkan dengan tingkat pendidikan yang sandang oleh sebagian besar masyarakat dan ketrampilan kewirausahaan yang dimiliki. Adapun jumlah tenaga kerja yang tersebar berdasarkan jenis usaha yaitu 45 orang bekerja pada perusahaan menengah, 14 orang bekerja pada perusahaan kecil, dan 37 orang bekerja diusaha mikro.

Berdasarkan uraian kondisi Kota Gunungsitoli khususnya kecamatan Idanoi dapat dilihat terdapat permasalahan yang dihadapi berupa kurangnya sarana pendukung pembelajaran, masih sedikitnya jumlah UMKM masyarakat, kurangnya posyandu menyebabkan kurang adanya penyuluhan kesehatan sehingga berdampak jangka panjang terhadap kesehatan masyarakat khususnya balita. Oleh karena itu, melalui PT Pertamina (Persero) MOR I-TBBM Gunungsitoli melaksanakan program pertanggungjawaban sosial dan lingkungan dalam menyelesaikan permasalahan tersebut yang bermitra dengan Rumah Zakat dan merupakan rekanan kepada masyarakat dalam komunitas kehidupan local (Ekawati, 2007). Hal ini merupakan realisasi dan kepatuhan PT Pertamina terhadap peraturan perundang Undang-Undang Perseroan Terbatas pasal 1 angka 3 
mengenai tanggung jawab sosial dan lingkungan, Peraturan Pemerintah No 47 Tahun 2012 pasal 4 dan pasal 6 tentang pelaksanaan tanggung jawab sosial dan lingkungan yang dilaksanaan oleh direksi berdasarkan kegiatan kerja tahunan dan dilaporkan pada laporan tahunan perseroan, Undang-Undang No 25 Tahun 2017 tentang Penanaman Modal Asing yang diatur pada Pasal 15 huruf b mengenai hubungan yang serasi, seimbang dan sesuai dengan lingkungan, nilai, norma, dan budaya masyarakat setempat, Undang-Undang No. 32 Tahun 2009 tentang perlindungan dan pengelolaan lingkungan hidupa yang tertera pada pada pasal 68 . Peraturan Menteri Badan Usaha Milik Negara No. PER-08/MBU/2013 Tahun 2013 Tentang Perubahan Keempat Atas Peraturan Menteri Negara Badan Usaha Milik Negara No. PER-05/MBU/2007 Tentang Program Kemitraan Badan Usaha Milik Negara Dengan Usaha Kecil Dan Program Bina Lingkungan, dan Undang-Undang No 22 Tahun 2001 mengenai Minyak dan Gas Bumi pada pasal 11 ayat (3) huruf p dan pasal 40 ayat (5). Oleh karena itu, artikel ini menjelaskan program pertanggungjawaban yang dilakukan PT Pertamina (Persero) MOR I-TBBM Gunungsitoli yang bergerak dibidang minyak dan gas bumi terhadap sosial dan lingkungan di Kec. Gunungsitoli Idanoi khususnya Desa Humene yang bertujuan meningkatkan kesejahteraan dan tercapainya pembangunan nasional secara merata dan menyeluruh. Adapun pelaksanaan program CSR ini didasarkan pada local wisdom dikarenakan masyarakat disetiap daerah memiliki karakteristik yang berbeda sehingga diperlukan pemahaman kondisi masyarakat sehingga tercipta suatu badan usaha sebagai agent of development (Budiarti \& Santoso, 2014).

\section{HASIL DAN PEMBAHASAN}

2.1 Peran Badan Usaha Dalam Meningkatkan Kesejahteraan Melalui Pengembangan Komunitas Lokal Sarana Dan Prasarana Pendukung Pembelajaran Dan Bantuan Dana Pendidikan

Di Era disruption sekarang ini, kita dituntut harus memiliki ketrampilan khususnya dibidang teknologi dan memiliki kompeten serta mampu bersaing dengan masyarakat lainnya (Wafi, 2016). Oleh karena itu, perlu mempersiapkan sumber daya manusia (SDM) yang memiliki ketrampilan dan pengetahuan. Salah satu faktor dalam mempersiapkan SDM tersebut melalui pendididkan yang ditempuh dari pendidikan dasar sampai dengan perguruan tinggi. Disamping itu, dalam mencapai pembangunan nasional yang berlandasan terhadap kesejahteraan masyarakat yang adil dan merata, pendidikan sangatlah berperan penting dalam menunjang tujuan tersebut.

Pendidikan merupakan investasi yang besar bagi masyarakat karena merupakan modal untuk memperoleh pekerjaan dan kehidupan layak (Ulfa, 2015). Berdasarkan Undang-Undang No 20 Tahun 2003 pasal 3 disebutkan bahwa pendidikan nasional berfungsi mengembangkan kemampuan dan membentuk watak serta mencerdaskan kehidupan bangsa. Sehingga pentingnya pendidikan menjadi faktor utama dalam membangun manusia untuk mencapai kesejahteraan. Salah satu faktor pendukung terlaksananya pendidikan adalah adanya sarana dan prasarana pendukung pendidikan. Sarana dan prasarana tersebut berupa tersedianya fasilitas sekolah yang didalamnya terdapat ruang belajar, perpustakaan, ruang laboratorium, dan segala sesuatu yang mendukung proses belajar mengajar. Disamping itu, adanya bantuan dalam dana pendidikan (Fadhilah, 2014) juga mendukung terciptanya proses belajar mengajar yang baik seperti beasiswa pendidikan yang diberikan kepada siswa yang tidak mampu dan berprestasi sehingga dapat melanjutkan pendidikan yang lebih tinggi.

Menurut data BPS tahun 2017 bahwa Kota Gunungsitoli memiliki 27 sekolah yang tersebar di masing-masing desa. Sedangkan jumlah penduduk secara keseluruhan dari kota ini sebanyak 135995 jiwa. Sehingga untuk memenuhi sarana dan prasarana pemenuhan kebutuhan pendidikan nasional masih sangatlah kurang. Disamping itu, banyak daerah yang juga belum memiliki pendidikan merata menyebabkan pemerintah masih lebih memprioritaskan dalam membangun sarana dan prasarana didaerah lain sehingga pada Kota Gunungsitoli masih sangatlah kurang dalam pembangunan sarana dan prasarana pendidikan.

Masih rendahnya pendapatan yang diperoleh masyarakat juga menjadi faktor kurangnya pencapaian pendidikan yang lebih tinggi. Hal ini dikarenakan tidak adanya biaya untuk melanjutkan pendidikan yang lebih tinggi sehingga banyak masyarakat yang hanya bisa mengemban pendidikan sebatas pendidikan dasar, pertama ataupun menengah. Oleh karena itu, peran masyarakat, pemerintah, dan badan usaha sekitar dalam menyediakan sarana dan prasarana pendidikan serta bantuan pendidikan sangatlah penting dalam meningkatkan tujuan pendidikan nasional dalam menciptakan kesejahteraan masyarakat yang adil dan merata. Oleh karena itu, program CSR PT Pertamina (Persero) MOR I-TBBM Kota Gunungsitoli bertujuan membantu meningkatkan mutu pendidikan dengan memberikan sarana pendidikan kepada sekolah dan pemberian beasiswa berprestasi

\subsection{Usaha Mikro Kecil dan Menengah Dalam Mengembangkan Perekonomian Lokal}

Salah satu penggerak dan pembangunan daerah adalah melalui pengembangan ekonomi lokal. Dimana dengan mengembangkan produk-produk lokal yang terdapat didaerah sehingga masyarakat menjadi lebih mandiri dan peningkatan perekonomian oleh masyarakat. Disamping itu juga adanya pengembangan usaha kecil daerah akan memperkenalkan produk unggul daerah kepasar nasional maupun internasional (Syukriah \& Hamdani, 2013) dan berdampak terhadap peningkatan PDB daerah maupun nasional. 
Pengembangan produk lokal skala kecil merupakan faktor pendorong dalam meningkatkan sumber pendapatan bagi masyarakat (Taib \& Roswita, 2018) dan merupakan produk yang banyak dihasilkan oleh rumah tangga (Qomaruddin, Sofiana, Susilo, \& Subadriyah, 2017). Hal ini dikarenakan masyarakat lebih mandiri dalam membuat usaha serta memperkenalkan produk unggulan dari daerahnya. Adapun produk yang dihasilkan seperti gorengan, kripik, kue kering, dan produk lokal lainnya. Produk ini juga mempunyai potensi yang besar dalam pasar perdagangan bebas dikarenakan produk yang belum tentu ada dinegara lain. Sehingga adanya pengembangan produk lokal akan berdampak terhadap peningkatan pendapatan dan kesejahteraan masyarakat secara luas.

Tetapi terdapat permasalahan yang dihadapi dalam pengembangan produk lokal ini seperti masih kurangnya kreativitas dalam diversifikasi produk, kurangnya penggunaan teknologi dalam memproduksi produk (Taib \& Roswita, 2018), serta masih lemahnya pengetahuan masyarakat mengenai pemasaran produk secara nasional maupun internasional. Sehingga peran penting masyarakat, pemerintah dan badan usaha sangatlah penting dalam mengembangkan UMKM lokal untuk meningkatkan perekonomian masyarakat.

Salah satunya adalah Kecamatan Gunungsitoli Idanoi. Kecamatan ini memiliki usaha besar 2, menengah 6, kecil 29 dan mikro sebanyak 881. Dari perbandingan tersebut tampak bahwa usaha kecil dan mikro merupakan usaha dominan yang banyak dikelolah oleh masyarakat pada kecamatan ini. Khususnya di Desa Humene yang memiliki usaha menengah sebanyak 1 unit, kecil 2 unit, dan mikro sebanyak 10 unit sehingga mayoritas masyarakat disana banyak melakukan usaha mikro. Adapun usaha yang banyak dikembangkan disana adalah berupa usaha produksi kripik, gorengan dan kue kecil. Tetapi terdapat permasalahan yang dihadapi masyarakat seperti kurang diversifikasi produk, kurangnya pemahaman mengenai kewirausahaan dan manajemen bisnis, serta masih sempitnya pemasaran produk oleh pelaku usaha. Oleh karena itu. PT Pertamina (Persero) MOR I-TBBM Kota Gunungsitoli memberikan bantuan dan pendampingan yang bertujuan untuk meningkatkan kapasitas dan kompetensi penerima manfaat dalam melakukan aktivitas ekonomi usahanya dan meningkatkan income/pendapatan dan kualitas hasil produksi penerima manfaat sebagai program keperdulian terhadap sosial dan lingkungan.

\subsection{Pipanisasi Saluran Air Bersih Bagi Masyarakat Rural Kota Gunungsitoli}

Air merupakan sumber kehidupan bagi semua makhluk hidup untuk kelangsungan hidupnya (Azmeri, Fauzi, \& Mutiawati, 2012). Tanpa air, makhluk hidup khususnya manusia tidak akan dapat bertahan hidup lama. Air digunakan untuk memenuhi kebutuhan seperti makan, mandi, mencuci pakaian, serta kebutuhan lainnya yang menunjang kehidupannya. Tetapi sekarang ini air bersih sudah sulit untuk diperoleh hal ini dikarenakan limbah yang dihasilkan dari industri dan rumah tangga yang berdampak terhadap pencemaran air bersih (Partnership, 2017). Banyak masyarakat yang harus berjalan jauh demi memperoleh kebutuhan air bersih. Dikota-kota besar yang memiliki banyak gedunggedung besar seperti Jakarta, Medan, Bandung, Surabaya dan kota besar lainnya, air bersih sudah sangat sulit diperoleh bahkan dalam memperoleh air bersih untuk konsumsi harus mengeluarkan biaya yang cukup besar. Oleh karena itu, pentingnya pemeliharaan air bersih untuk menjamin kelangsungan hidup jangka panjang bagi makhluk hidup di Bumi.

Di Kota Gunungsitoli, ketersediaan air bersih juga menjadi perhatian penting dari pemerintah daerah dan masyarakat. Hal ini dikarenakan kota tersebut memiliki geografis yang sebagian besar pesisir pantai. Akibatnya mayoritas daerah tersebut memiliki air yang terasa asin dikarenakan dekat dengan pantai. Disamping itu, pada sebagian kecil wilayah Kecamatan Gunungsitoli Idanoi, pasokan air bersih juga masih sangatlah kurang. Hal ini dikarenakan daerah tersebut dekat pesisir pantai dan wilayah daerah sebagian besar bebatuan sehingga sulit memperoleh pasokan air bersih untuk kebutuhan sehari-hari. Masyarakat harus berjalan jauh dalam memperoleh air bersih serta mengeluarkan biaya yang besar. Sehingga perlu dilakukan distribusi melalui pipanisasi saluran air bersih kepada masyarakat dalam menyelesaikan permasalahan tersebut. Oleh karena itu, melalui program CSR PT. Pertamina (Persero) MOR ITBBM Kota Gunungsitoli, dilakukan pipanisasi saluran air bersih kepada masyarakat yang bertujuan untuk menyediakan kebutuhan air bersih untuk warga kurang mampu

\subsection{Optimalisasi Peran Posyandu SEHATI Desa Humene di Kota Gunung Sitoli}

Kesehatan merupakan tanggung jawab kita bersama yaitu masyarakat, pemerintah dan badan usaha. Dalam menciptakan suatu masyarakat yang sejahtera dan mencapai tujuan pembangunan nasional, kesehatan merupakan salah satu faktor utama untuk mencapai tujuan tersebut. Berdasarkan Undang-Undang Kesehatan No 36 Tahun 2009 dijelaskan bahwa pembangunan kesehatan pada masyarakat bertujuan untuk meningkatkan kesadaran, kemauan, dan kemampuan hidup sehat bagi setiap orang khususnya perhatian kepada bayi dibawah lima tahun (balita). Perhatian kesehatan terhadap balita merupakan upaya untuk mempertahankan kelangsungan hidup serta meningkatkan kualitas hidup dari anak agar mencapai tumbuh kembang yang optimal (Hendrawati et al., 2018) disamping itu juga pada masa ini merupakan masa yang rentan bayi terhadap penyakit dan gizi dan merupakan masa yang cukup pendek (Wibawa, Herniyatun, \& Sarwono, 2013)sehingga perlu perhatian kesehatan oleh orang tua. Oleh karena itu, pentingnya fasilitas kesehatan yang tersedia di kecamatan dan desa sangat menjamin kesehatan masyarakat dan bayi demi tercapainya pembangunan nasional. Adapun fasilitas kesehatan berupa rumah sakit, puskesmas dan 
posyandu. Ketersediaan fasilitas kesehatan ini sangatlah penting dan menjadi pekerjaan rumah yang besar bagi semua kalangan pihak.

Berdasarkan data BPS diperoleh informasi bahwa Kota Gunungsitoli memiiki rumah sakit sebanyak 1 unit, puskesmas 6 unit dan posyandu 171 unit. Jika dibandingkan dengan jumlah penduduk pada kota ini yaitu 135.995 jiwa maka fasilitas kesehatan masihlah kurang sehingga perlu perhatian dari semua elemen dalam memanfaatkan secara maksimal fasilitas kesehatan yang dimiliki. Salah satu pemanfaatan maksimal tersebut adalah tersedianya posyandu dimana jumlahnya sebesar. Pada Kecamatan Gunungsitoli Idanoi, fasilitas kesehatan yang dimiliki terdiri dari 1 puskesmas dan 31 posyandu yang tersebar pada 26 desa sehingga masing-masing desa terdapat 1 posyandu. Khususnya pada Desa Humene, dimana hanya memiliki fasilitas kesehatan berupa 1 posyandu yang dikelola oleh 1 bidan sehingga dalam pemenuhan kebutuhan kesehatan masyarakat khususnya balita masih sangatlah kurang jika dibandingkan dengan jumlah penduduk pada desa tersebut. Oleh karena itu, PT Pertamina (Persero) MOR I-TBBM Kota Gunungsitoli melakukan kegiatan CSR yang bertujuan untuk mewujudkan peningkatan status Posyandu dengan meningkatkan pengelolaan, peningkatan kualitas dan keterampilan sumberdaya, serta meningkatkan kemitraan dengan berbagai stakeholder.

Oleh karena itu, penting peran masyarakat dalam memaksimalkan posyandu dalam menjamin tersedianya fasilitas kesehatan. Dalam pelaksanaanya, posyandu merupakan kegiatan yang dilakukan masyarakat yang dikader untuk pembangunan kesehatan dibawah pengawasan dari kementerian kesehatan (Assa, Umboh, \& Raule, 2014; Dewi, 2017; Saepudin, Rizal, \& Rusman, 2017; Syamsi, 2017). Adapun kegiatan posyandu tersebut berupa berkaitan mengenai edukasi mengenai kesehatan, diseminasi, fasilitas/pendampingan, konsultasi, supervise, pemantauan dan evaluasi (Dewi, 2017). Sebagian besar fokus utama dari posyandu adalah edukasi kesehatan terhadap orang tua yang memiliki bayi dibawah lima tahun (balita). Pada Desa Humene, masih banyak permasalahan yang dihadapi orang tua yang memiliki bayi dimana kurangnya pemahaman pemenuhan gizi terhadap bayi, kesehatan bayi, dan informasi lainnya yang berguna terhadap tumbuh kembang bayi. Terdapat perbedaan berat badan dan kesehatan yang dialami bayi bagi ibu yang sering melakukan pengecekan kesehatan di posyandu dengan yang tidak seperti bayi yang memiliki berat badan dibawah standar pada usianya (Destiadi, Nindya, \& Sumarmi, 2015; Novitasari, Destriatania, \& Febry, 2016), kurangnya pertumbuhan bayi pada usianya. Oleh karena itu, pentingnya dalam optimalisasi peran posyandu melalui pengkaderan masyarakat (Assa et al., 2014; Haryati,
Muthmainnah, \& Fatimaningrum, 2015; Saepudin et al., 2017; Syamsi, 2017; Wibawa et al., 2013) dalam meningkatkan kesehatan serta kesadaran hidup sehat dimasyarakat khususnya orang tua yang memiliki anak dibawah lima tahun atau balita.

\subsection{Revitalisasi Sarana Pendukung Pembelajaran dan Bantuan Dana Pendidikan Bagi Siswa SD- SMP-SMA Berprestasi}

Sarana pendukung pembelajaran masih sangatlah kurang di berbagai kecamatan di Kota Gunungsitoli. Oleh karena itu, perlu dilakukan peningkatan sarana pendukung pembelajaran yang tujuannya meningkatkan minat belajar siswa. Disamping itu, kecilnya pendapatan yang diperoleh masyarakat juga menjadi hambatan dalam melanjutkan pendidikan ke jenjang yang lebih tinggi. Oleh karena itu, PT Pertamina (Persero) MOR I-TBBM Gunungsitoli melakukan kegiatan pertanggungjawaban sosial dan lingkungan dengan merevitalisasi sarana pendukung pembelajaran dan memberikan bantuan pendidikan bagi 6 sekolah (SD-SMP-SMA). Sebagai agen pembangunan nasional (agent of development) yang berperan aktif untuk memastikan jalannya pembangunan yang merata di seluruh lingkup wilayah operasionalnya, PT. PERTAMINA (Persero) MOR I TBBM Gunung Sitoli merealisasikan komitmen yang dimaksud melalui realisasi CSR untuk meningkatkan capaian pada program-program prioritas pemerintah di bidang pendidikan dan kebudayaan secara khusus di Kota Gunung Sitoli. Dedikasi ini menyasar kepada upaya meningkatkan nilai tambah bagi masyarakat secara berkesinambungan dengan penyaluran bantuan bagi perbaikan akses dan kualitas layanan pendidikan di sekolah-sekolah dalam berbagai jenjang pendidikan di wilayah Kota Gunung Sitoli. Adapun kegiatan realisasi program CSR PT Pertamina (Persero) MOR ITBBM Gunungsitoli dapat dideskripsikan pada tabel 1 dibawah ini. 
Tabel 1. Deskripsi Program Revitalisasi Sarana Pendukung Pembelajaran dan Bantuan Dana Pendidikan

\begin{tabular}{|c|c|c|}
\hline Tahapan Program & Hasil Program & Dampak Program \\
\hline $\begin{array}{ll}\text { - } & \text { Konsultasi dengan stakeholders } \\
\text { - } & \text { Musyawarah masyarakat } \\
\text { - } & \text { Perencanaan pelaksanaan } \\
\text { kegiatan } \\
\text { - } & \text { Pemberian bantuan } \\
\text { - } & \text { Revitalisasi sarana pendukung } \\
\text { pembelajaran }\end{array}$ & $\begin{array}{ll}\text { - } & \text { Tersedianya fasilitas } \\
\text { pendukung } & \text { proses } \\
\text { pembelajaran } & \\
\text { Berlanjutnya pendidikan yang } \\
\text { sempat tertundar }\end{array}$ & $\begin{array}{l}\text { - Kesadaran masyarakat yang } \\
\text { lebih tinggi mengenai } \\
\text { pentingnya pendidikan untuk } \\
\text { masa depan } \\
\text { - } \\
\text { Peningkatan prestasi bagi anak- } \\
\text { anak dalam pendidikan. } \\
\text { - Terjaminnya kualitas hidup } \\
\text { melalui peningkatan } \\
\text { pendidikan yang diperoleh. } \\
\text { Masa depan yang lebih baik } \\
\text { dikarenakan memperoleh } \\
\text { pekerjaan yang lebih layak }\end{array}$ \\
\hline
\end{tabular}

Realisasi program CSR oleh TBBM Gunung Sitoli pada lingkup pendidikan ini dimanifestasikan dalam bentuk penyaluran bantuan sarana penunjang pembelajaran sebanyak 6 (enam) paket kepada 6 (enam) sekolah (SD-SMP-SMA) di wilayah Kota Gunung Sitoli. Dalam kesempatan yang sama, TBBM Gunung Sitoli juga menyalurkan bantuan pendidikan kepada 36 siswa SD-SMP-SMA berprestasi di wilayah yang sama. Bantuan dana pendidikan ini menjadi motivasi tersendiri bagi peningkatan prestasi para siswa dalam mengharumkan wilayah Kabupaten Nias melalui prestasi siswa didik di kancah Regional Sumatera maupun untuk skala nasional. Disisi lain, pengadaan sarana dan prasarana pendidikan atas inisiatif PT. PERTAMINA (Persero) MOR I - TBBM Gunung Sitoli ini meningkatkan efektiftas dan efisiensi pengelolaan administrasi sarana dan prasarana akademik yang turut meningkatkan kualitas proses pembelajaran di sekolah-sekolah penerima manfaat, khususnya di pengelolaan aktivitas keperpustakaan, penyusunan kurikulum, dan ekstrakurikuler

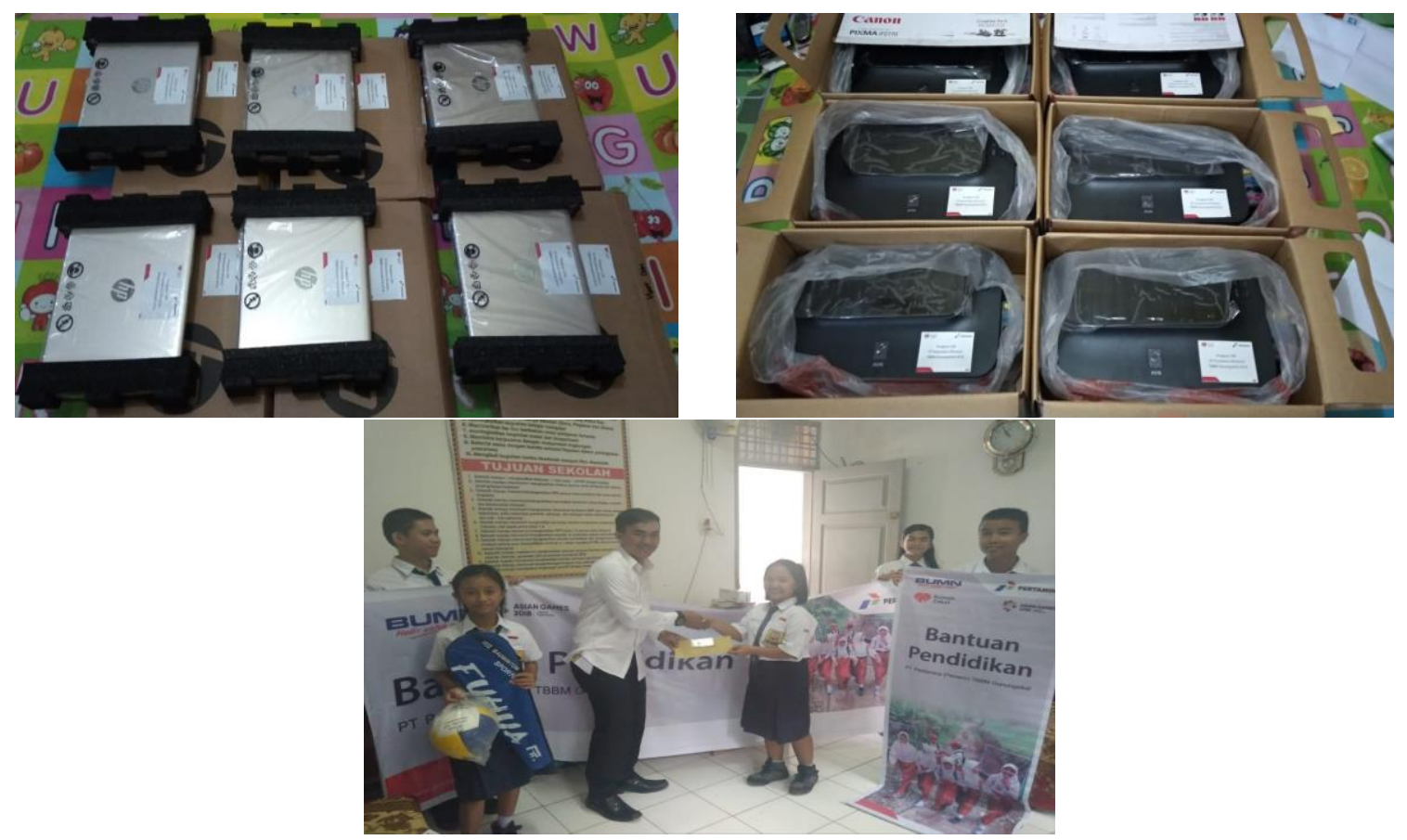

Gambar 1. Revitalisasi Sarana Pendukung Pembelajaran dan Bantuan Dana Pendidikan

\subsection{Pengembangan Produk Makanan Ringan Usaha Mikro Desa Humene di Kota Gunung Sitoli}

Industri pangan lokal merupakan sumber pendapatan bagi masyarakat (Taib \& Roswita, 2018). Oleh karena itu, perlu pengembangan produk makanan lokal untuk meningkatkan kesejahteraan dan pembangunan nasional. Salah satunya pada Desa Humene Kec. Gunungsitoli Idanoi. Program inisiasi usaha ekonomi masyarakat dengan sasaran calon wirausaha dari 
kelompok ibu rumah tangga di Desa Humene Kota Gunung Sitoli merupakan manifestasi unggulan strategis lainnya yang telah direalisasikan oleh PT. PERTAMINA (Persero) MOR I - TBBM Gunung Sitoli. Aktualisasi CSR ini diwujudkan melalui pelatihan dan pendampingan usaha berupa manajemen bisnis, produksi dan pemasaran dari produk yang dihasilkan oleh 10 (empat) kelompok usaha yang telah dibentuk dengan masing-masing anggota berjumlah 4 (empat) orang serta penyerahan bantuan modal usaha dan peralatan penunjang operasional produksi keripik, gorengan dan kue kecil kepada masing-masing kelompok usaha.

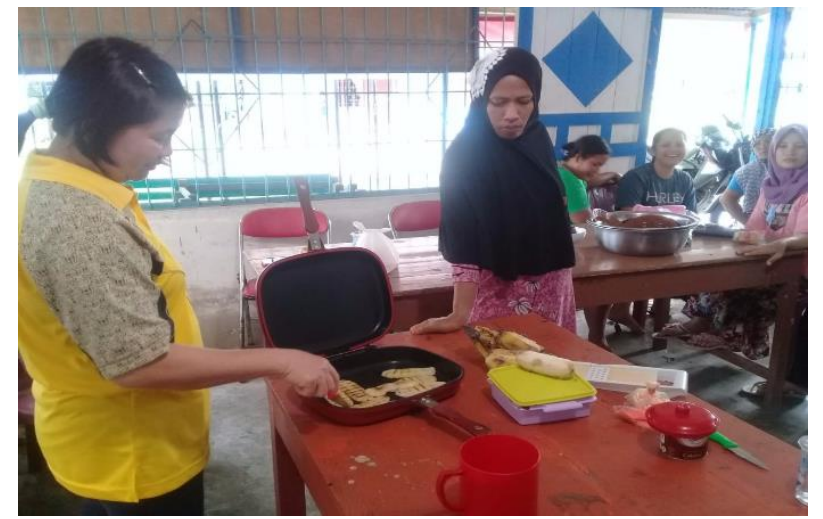

PT. PERTAMINA (Persero) MOR I - TBBM Gunung Sitoli menaruh perhatian serius kepada pengembangan usaha mikro dan kecil di Kota Gunung Sitoli khususnya di Desa Humene dimana mayoritas dari penggiat usaha telah menjalankan usahanya selama bertahun-tahun. Resistensi pelaku usaha mikro di Desa Humene ini menunjukkan bahwa usaha yang mereka geluti mampu menghidupi keluarganya secara berkelanjutan dan para pelakunya juga memiliki keterampilan yang relevan dalam perniagaan yang memberikan keuntungan finansial walaupun relatif belum optimal.

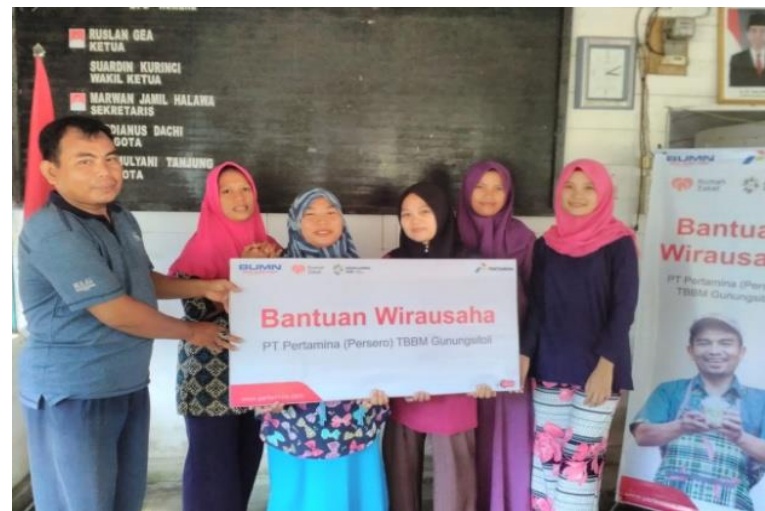

Gambar 2. Kegiatan Pengembangan Produk Makanan Ringan Usaha Mikro Desa Humene

Orientasi inilah yang menjadi fokus bagi PT. PERTAMINA (Persero) MOR I - TBBM Gunung Sitoli dalam penyaluran bantuan yang memenuhi kualifikasi kelayakan dan urgensi penerima manfaat dalam konteks yang sebenarnya. Dengan dukungan bantuan modal usaha dan modal kerja sebagai stimulus operasional pelaku usaha mikro di Desa Humene telah mengoptimalkan kapasitas pasokan komoditi bisnis mereka melalui pengadaan barang ke grosir besar sehingga memberikan margin keuntungan yang lebih besar sekaligus meningkatkan kesejahteraan para pelaku usaha mikro setempat. Adapun kegiatan realisasi program CSR PT Pertamina (Persero) MOR I-TBBM Gunungsitoli dapat dideskripsikan pada tabel 2 dibawah ini.

Tabel 2. Deskripsi Program Pengembangan Produk Makanan Ringan Usaha Mikro Desa Humene

\begin{tabular}{|c|c|c|}
\hline Tahapan Program & Hasil Program & Dampak Program \\
\hline $\begin{array}{l}\text { - } \text { Konsultasi dengan stakeholders } \\
\text { - } \quad \text { Musyawarah masyarakat } \\
\text { - } \text { Perencanaan pelaksanaan } \\
\text { - } \text { Pelatihan dan pendampingan } \\
\text { manajemen bisnis } \\
\text { - Pelatihan dan pendampingan } \\
\text { produksi dan pemasaran }\end{array}$ & $\begin{array}{l}\text { - } \begin{array}{l}\text { Penggunaan teknologi dalam } \\
\text { melakukan proses produksi }\end{array} \\
\text { - } \begin{array}{l}\text { Pengetahuan mengenai } \\
\text { manajemen bisnis dalam } \\
\text { mengelola bisnis }\end{array} \\
\text { - Adanya produk lokal yang } \\
\text { beragam } \\
\text { - } \begin{array}{l}\text { Pengetahuan pemasaran lebih } \\
\text { luas untuk produk lokal. }\end{array}\end{array}$ & 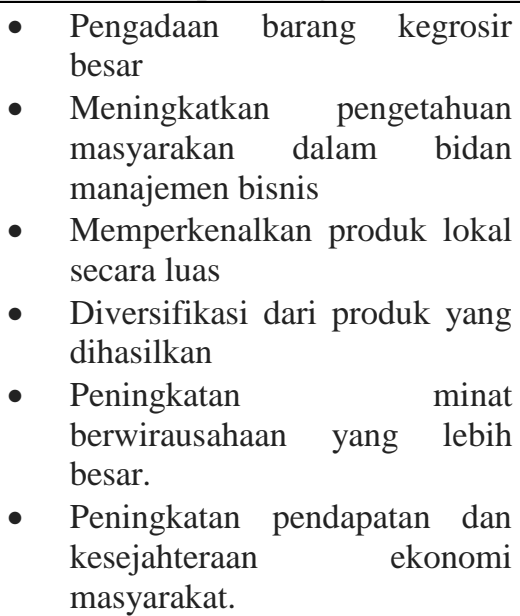 \\
\hline
\end{tabular}




\subsection{Pipanisasi Saluran Air Bersih Bagi Masyarakat Rural Kota Gunung Sitoli}

Air merupakan sumber kehidupan dan kelangsungan hidup bagi makhluk hidup khususnya manusia(Azmeri et al., 2012). Sekarang ini kebutuhan akan air bersih sudah sangat sulit dikarenakan pencemaran oleh industri dan rumah tangga. Kota Gunungsitolo, kebutuhan air bersih mengalami kesulitan dikarenakan daerah yang dekat pesisir pantai serta sumber air bersih yang jauh. Disamping itu, sebagian besar penduduk di kota ini khususnya Desa Humene mayoritas masyarakatnya miskin. Sehingga, melalui CSR dari PT Pertamina (Persero) MOR I-TBBM Gunungsitoli dilakukan penyelesaian masalah tersebut.
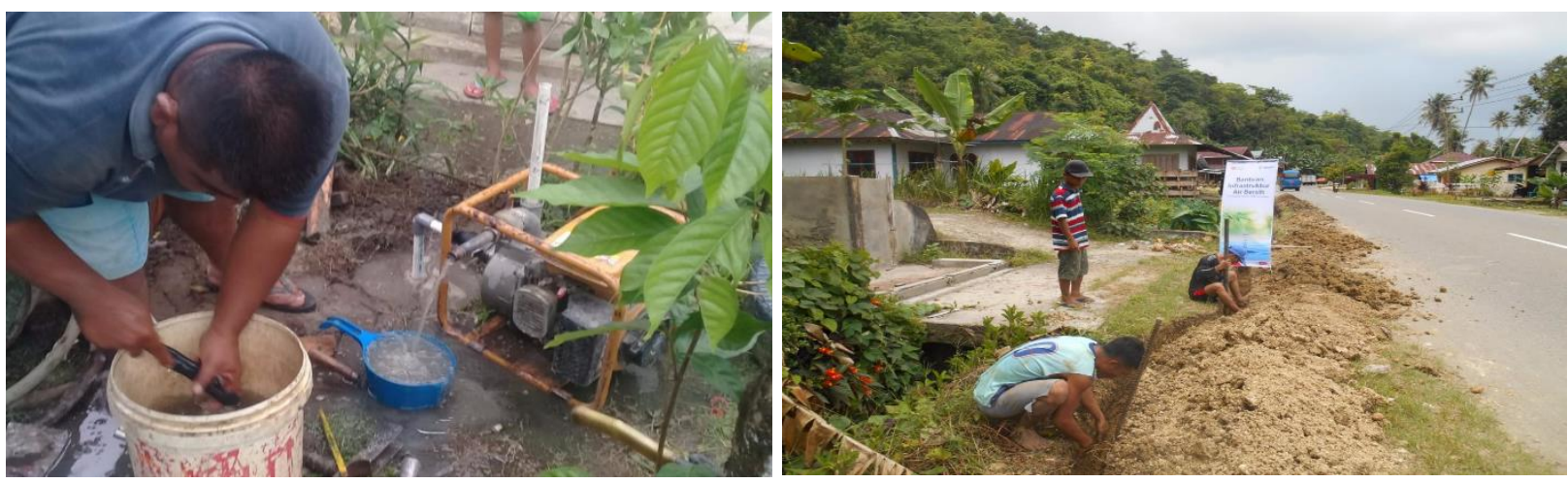

Gambar 3. Program Pipanisasi Saluran Air Bersih Bagi Masyarakat Kota Gunungsitoli

Realisasi program CSR oleh PT. PERTAMINA (Persero) MOR I - TBBM Gunung Sitoli dalam lingkup sosial ini diwujudkan dalam bentuk pemberdayaan masyarakat dalam instalasi air bersih kepada 10 (sepuluh) kepala rumah tangga yang berdomisili di Desa Humene Kota Gunung Sitoli. Kegiatan ini juga dibarengi dengan edukasi pelayanan dasar masyarakat tentang air bersih bagi peningkatan kualitas kesehatan, budaya bersih dan sanitasi di lingkungan masyarakat miskin Kota Gunung Sitoli. Dalam menjaga kesinambungan sarana air bersih dan sanitasi yang telah dibangun di wilayah setempat juga dibutuhkan pengelolaan sarana yang berasal dari masyarakat yang berdomisili di lokasi penerima manfaat. Komitmen ini terus dijaga keberlangsungannya oleh PT. PERTAMINA (Persero) MOR I - TBBM Gunung Sitoli melalui pendampingan dan kampanye pengelolaan air bersih dan sanitasi lingkungan yang berkelanjutan kepada penerima manfaat di Kota Gunung Sitoli yang berjumlah .sebanyak 10 rumah tangga. Kini seluruh penerima manfaat telah merasakan fasilitas air bersih secara mandiri yang bepengaruh secara signifikan terhadap peningkatan kualitas hidup dan kesehatan para anggota rumah tangga yang dimaksud. Adapun kegiatan realisasi program CSR PT Pertamina (Persero) MOR I-TBBM Gunungsitoli dapat dideskripsikan pada tabel 3 dibawah ini.

Tabel 3. Deskripsi Program Pipanisasi Saluran Air Bersih Bagi Masyarakat Rural Kota Gunung Sitoli

\begin{tabular}{|c|c|c|}
\hline Tahapan Program & Hasil Program & Dampak Program \\
\hline $\begin{array}{l}\text { - } \text { Konsultasi dengan stakeholders } \\
\text { - Musyawarah masyarakat } \\
\text { - Memberdayakan masyarakat } \\
\text { dalam membangun pipanisasi } \\
\text { saluran air bersih } \\
\text { - Edukasi pelayanan dasar } \\
\text { masyarakat mengenai air bersih } \\
\text { bagi peningkatan kualitas } \\
\text { kesehatan, budaya bersih dan } \\
\text { sanitasi dilingkungan } \\
\text { masyarakat miskin }\end{array}$ & $\begin{array}{l}\text { - Tersedianya air bersih di } \\
\text { beberapa rumah tangga. } \\
\text { - Pengetahuan air bersih } \\
\text { berdampak terhadap kesehatan } \\
\text { lingkungan }\end{array}$ & 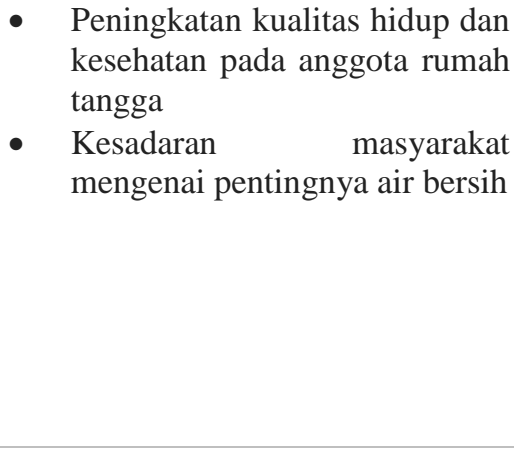 \\
\hline
\end{tabular}

\subsection{Optimalisasi Peran Posyandu SEHATI Desa Humene Bagi Tumbuh Kembang Balita}

Kesehatan bayi dibawah lima tahun (balita) sangatlah penting karena merupakan umur yang rentan terhadap penyakit dan gizi buruk (Hendrawati et al., 2018; Wibawa et al., 2013). Pengetahuan ibu terhadap gizi anak sangatlah penting untuk menjamin tumbuh kembang anak kedepannya. Oleh karena itu, perlu kiranya adanya fasilitas kesehatan seperti posyandu yang tujuannya memberikan edukasi dan mengamati tumbuh kembang anak agar terhindar dari gizi buruk (Assa et al., 2014; Destiadi et al., 2015; Novitasari et 
al., 2016; Syamsi, 2017). Banyak permasalahan yang dihadapi ibu pada anaknya di Desa Humene Kec. Gunungsitoli Idanoi seperti kurangnya gizi bagi anak, mudah terserang penyakit, kurang memiliki kesadaran mengenai kebersihan lingkungan, dan kurangnya konsumsi makanan tambahan. Selaras dengan program CSR di bidang kesehatan yang dilaksanakan di berbagai wilayah operasional PT. PERTAMINA (Persero) MOR I, TBBM Gunung Sitoli juga menitikberatkan pelaksanaan program kesehatan masyarakat khususnya kategori ibu hamil, ibu menyusui dan balita

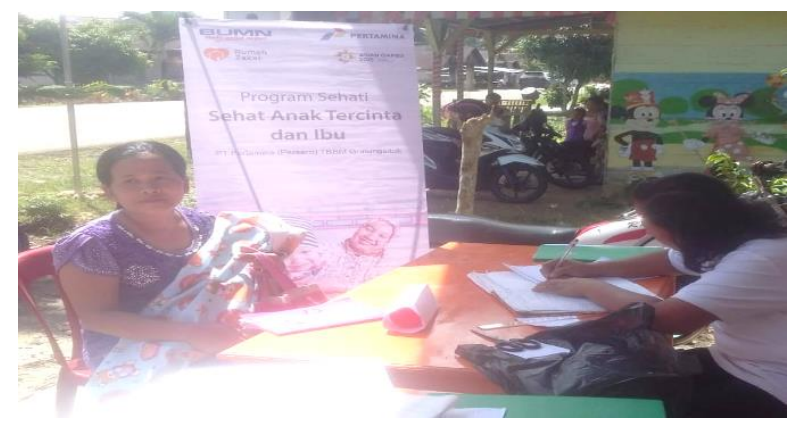

di Desa Humene. Aktualisasi CSR TBBM Gunung Sitoli berupa revitalisasi sarana posyandu serta didukung dengan aktivitas pemberian makanan tambahan, edukasi gizi ibu balita, pemantauan kesehatan ibu balita, dan home visit balita. Dari sisi peningkatan kapasitas SDM Posyandu, TBBM Gunung Sitoli juga melaksanakan rekrutmen kader baru dan capacity upgrading kader lama melalui pelatihan dan pembinaan kader posyandu dan pengadaan media edukasi.

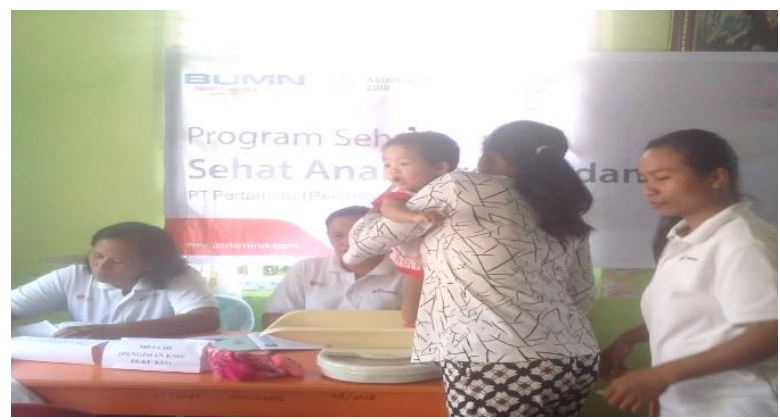

Gambar 4. Kegiatan Optimalisasi Posyandu SEHATI bagi masyarakat di Desa Humene

Kegiatan pembinaan yang dilakukan dengan koordinasi bersama stakeholder di Kota Gunung Sitoli telah menjadikan para kader sebagai agen dan edukator serta pelayan kesehatan kepada masyarakat dengan kompetensi dasar meliputi kesehatan dasar, gizi dan kesehatan reproduksi. Saat ini, Posyandu SEHATI di Desa Humene juga memiliki alat kesehatan seperti timbangan bayi, timbangan badan digital, dan alat ukur tinggi badan sesuai standar kebutuhan Posyandu. PT. PERTAMINA (Persero) MOR I, TBBM Gunung Sitoli memberikan penekanan penting pada komitmen ini sebagai upaya untuk membangun kesuksesan bersama dengan masyarakat lokal khususnya dalam akselerasi capaian tujuan pembangunan kesehatan di wilayah setempat sesuai amanah pembangunan nasional. Adapun kegiatan realisasi program CSR PT Pertamina (Persero) MOR I-TBBM Gunungsitoli dapat dideskripsikan pada tabel 4 dibawah ini. Hasil dari program ini yaitu terlaksananya pelatihan kader posyandu dalam rangka meningkatkan pengetahuan kader posyandu, fasilitas posyandu yang lengkap untuk pemantauan tumbuh kembang balita, adanya pendamping posyandu secara intensif untuk meningkatkan kualitas posyandu.

Tabel 4. Deskripsi Program Optimalisasi Peran Posyandu SEHATI Desa Humene Bagi Tumbuh Kembang Balita

Tahapan Program

- Konsultasi stakeholders

- Musyawarah masyarakat

- Mengkader masyarakat sebagai bagian dari posyandu

- Revitalisasi sarana posyandu.

- Edukasi dan pemberian makanan tambahan selain ASI.

- Edukasi gizi ibu balita

- Pemantauan kesehatan ibu balita dan home visit balita

Hasil Program

Tersedianya fasilitas pendukung kesehatan yang mempermudah mengawasi tumbuh kembangnya anak seperti timbangan bayi, timbangan badan digital, alat ukur tinggi badan.

- Ikut sertanya masyarakat dalam mendukung program posyandu meningkatkan kesehatan ibu dan balita.

- Pengetahuan kesehatan bagi ibu dan balita

- Peningkatan gizi bagi ibu dan anak.

- Pengamatan yang berkelanjutan terhadap balita.

\section{Dampak Program}

- Peningkatan kesehatan bagi ibu dan balita

- Peningkatan kesadaran bagi masyarakat untuk mengoptimalisasikan fasilitas kesehatan.

- Pengetahuan pentingnya kesehatan bagi ibu dan anak.

- Mengurangi jumlah gizi buruk bagi ibu dan balita.

- Peningkatan kesejahteraan masyarakat. 


\section{KESIMPULAN}

Pentingnya pemerataan pembangunan dalam meningkatkan kesejahteraan masyarakat merupakan tugas dari semua elemen tidak hanya pemerintah. Salah satunya adalah badan usaha dimana selama ini badan usaha hanya bertujuan mencari keuntungan dari kegiatan operasional yang dilakukan tanpa melihat dampat negatif dari aktifitas tersebut. Oleh karena itu, melalui peraturan yang diterbitkan pemerintah bahwa badan usaha juga harus memberikan kontribusi terhadap pembangunan nasional melalui program sosial dan pertanggung jawaban lingkungan dengan memberdayakan masyarakat lokal di wilayah operasionalnya.

Berdasarkan pengamatan diatas dapat diperoleh informasi bahwa CSR suatu perusahaan akan berdampak terhadap kesejahteraan dan penyelesaian masalah yang dihadapi masyarakat. Dimana penyelesaian tersebut didasarkan pada local wisdom yang ada pada masyarakat suatu daerah dengan memperhatikan karakteristik dari masyarakat tersebut (Budiarti \& Santoso, 2014). Adapun tanggung jawab sosial dan lingkungan yang dilakukan PT Pertamina (Persero) MOR I-TBBM Kota Gunungsitoli berupa revitalisasi sarana pendukung pembelajaran dan bantuan dana pendidikan bagi siswa SD-SMP-SMA berprestasi, pengembangan makanan ringan usaha mikro Desa Humene, pipanisasi saluran air bersih bagi masyarakat rural di Kota Gunungsitoli dan optimalisasi peran Posyandu SEHATI di Desa Humene. Hasil dari program CSR ini adalah masyarakat lebih mandiri dan terjadi peningkatan terhadap kesejahteraan dan perekonomian masyarakat sekitar. Adapun saran bagi program selanjutnya lebih memperhatikan kebutuhan priotitas dan permasalahan utama yang dihadapi oleh masyarakat. Disamping itu, perlu menghasilkan program yang memiliki keunggulan dibandingkan dengan program ataupun daerah lainnya sehingga menjadikan sentra keunggulan produk.

\section{DAFTAR PUSTAKA}

Assa, L., Umboh, A., \& Raule, J. (2014). Pengetahuan ibu balita usia 12-59 bulan tentang posyandu di amurang timur kabupaten minahasa selatan. Community Health, 1(2), 1-8.

Azmeri, Fauzi, A., \& Mutiawati, C. (2012). Survey dan pengembangan jaringan air minum kecamatan lembah sabil dan manggeng aceh barat daya. In Laporan Akhir Program Ipteks Bagi Masyarakat, Universitas Syiah Kuala.

Budiarti, M., \& Santoso, T. R. (2014). Corporate Social Responsibility (CSR) Dari Sudut Pandang Perusahaan. Social Work Journal, 4(1), 13-29.

Destiadi, A., Nindya, T. S., \& Sumarmi, S. (2015). Frekuensi Kunjungan Posyandu dan Riwayat Kenaikan Berat Badan sebagai Faktor Risiko Kejadian Stunting pada Anak Usia 3 - 5 Tahun. Media Gizi Indonesia, 10(1), 71-75.

Dewi, D. S. (2017). Peran Komunikator Kader Posyandu Dalam Meningkatan Status Gizi
Balita Di Posyandu Nurikelurahan Makroman Kecamatan Sambutan Kota Samarinda. Jurnal Ilmu Komunikasi, 5(1), 272-282.

Ekawati, H. (2007). Tanggung Jawab Sosial Perusahaan Dan Pemberdayaan Masyarakat Sekitar Perusahaan. Jurnal Kependudukan Dan Kebijakan, 18(1).

Ernawan, E. R. (2014). Tanggung Jawab Sosial Perusahaan - Corporate Social Responsibility. Jurnal Manajemen Dan Bisnis, 11(2), 219-242.

Fadhilah, N. I. (2014). Peranan Sarana dsn Prasarana Pendidikan Guna Menunjang Hasil Belajar Siswa Di SD Islam Al Syukro Universal. Skripsi.

Haryati, N., Muthmainnah, \& Fatimaningrum, A. (2015). Pelatihan Kader Posyandu Dalam Deteksi Perkembangan Anak Usia Dini. Jurnal Pendidikan Anak, 4(2), 651-658.

Hasanah, F. A. (2015). Peran CSR PT. Sari husada Dalam Pemberdayaan Masyarakat.

Hendrawati, S., Mardhiyah, A., Mediani, H. S., Nurhidayah, I., Mardiah, W., Adistie, F., \& Maryam, N. N. A. (2018). Pemberdayaan Kader Posyandu dalam Stimulasi Deteksi dan Intervensi Dini Tumbuh Kembang ( SDIDTK ) pada Anak Usia $0-6$ Tahun. Media Karya Kesehatan, 1(1), 39-58.

Mapisangka, A. (2009). Implementasi CSR terhadap Kesejahteraan Hidup Masyarakat. JESP, 1(1). Retrieved from http://fe.um.ac.id/wpcontent/uploads/2010/03/ANDI_M-CSR.pdf

Novitasari, Destriatania, S., \& Febry, F. (2016). Di Puskesmas Awal Terusan Determinants Occurrence Of Toddlers Below The Red Line In Health Center Of Awal Terusan. Jurnal Ilmu Kesehatan Masyarakat, 7(1), 48-63.

Pembangunan, P., \& Bersih, I. A. (2017). Percepatan Pembangunan Infrastruktur Air Bersih. Sustaining Partnership, 1-28.

Probosiwi, R. (2016). Tanggung Jawab Sosial Perusahaan dalam Peningkatan Kesejahteraan Masyarakat (Corporate Social Responsibility in Public Welfare Enhancement). Jurnal Socia, 13(2).

Qomaruddin, M., Sofiana, N., Susilo, E., \& Subadriyah. (2017). Pengembangan usaha makanan ringan kue jepit desa jambu timur. In seminar nasional hasil-hasil pengabdian (pp. 43-47).

Saepudin, E., Rizal, E., \& Rusman, A. (2017). Peran Posyandu Sebagai Pusat Informasi Kesehatan Ibu dan Anak Posyandu Roles as Mothers and Children Health Information Center. Record and Library Journal, 3(2), 201-208.

Suparman. (2013). Coorporate Social Responsibility: Bentuk Tanggung Jawab Sosial dan Suparman. Jurnal Interaksi, 2(2), 69-81.

Syamsi, A. A. (2017). Pelayanan kesehatan bagi balita di posyandu cempaka 2 kelurahan berbas tengah kecamatan bontang selatan kota bontang. EJournal Administrasi Negara, 5(1), 5243-5252. Syukriah, A., \& Hamdani, I. (2013). Peningkatan 
Eksistensi UMKM Melalui Comparative Advantage Dalam Rangka Menghadapi MEA 2015 Di Temanggung. Economics Development Analysis Journal, 2(2), 110-119.

Taib, G., \& Roswita, R. (2018). Analisis Prospek Dan Kendala Pengembangan Produk Industri Pangan Lokal* Di Sumatera Barat. Jurnal Teknologi Pertanian Andalas, 22(1), 96-101.

Ulfa, A. F. (2015). Pengaruh Sarana Prasarana Pendidikan Terhadap Minat Membaca Literatur Ekonomi Dan Prestasi Belajar Mata Pelajaran Ekonomi Siswa Kelas Xi Ips Sma Negeri 1 Jakenan Pati (Studi Pada Tahun Ajaran 2014/2015).

Wafi, M. I. (2016). Pengaruh pemanfaatan sarana dan prasarana belajar terhadap prestasi belajar pendidikan agama islam siswa kelas $x$ di sma $n$ 11 semarang.

Wibawa, Y. A., Herniyatun, \& Sarwono. (2013). Peran Kader Posyandu Dalam Pengaplikasian Stimulasi, Deteksi Dan Intervensi Dini Tumbuh Kembang Anak Di Desa Pucungkerep Kecamatan Kaliwiro Kabupaten Wonosobo. Jurnal Ilmiah Kesehatan Keperawatan, 9(1). 